\title{
(North) American Studies in Spain: between eclecticism and politics
}

\section{(2) OpenEdition \\ Journals}

Electronic version

URL: https://journals.openedition.org/ejas/409

DOI: 10.4000/ejas.409

ISSN: 1991-9336

Publisher

European Association for American Studies

Electronic reference

Francisco Collado Rodríguez, "(North) American Studies in Spain: between eclecticism and politics", European journal of American studies [Online], 1-1 | 2006, document 18, Online since 11 January 2006, connection on 13 July 2021. URL: http://journals.openedition.org/ejas/409 ; DOl: https://doi.org/ 10.4000/ejas.409

This text was automatically generated on 13 July 2021.

Creative Commons License 


\section{(North) American Studies in Spain: between eclecticism and politics}

1 At present, the Spanish university system does not offer any specific place for American Studies. In practical terms, this means that there is not such a thing as a degree in (North) American Studies for undergraduate students. The study of the history and culture of the United States of America is mostly disseminated all over the country in a number of departments of English, English-and English literature-still being the main subject of study in the only BA degree somehow related to our field of knowledge. Obviously, each English department is also free to allot the number of credits corresponding to the different disciplines to be covered in any English degree in Spain. This means that frequently the teaching of the English language is per se the centralized subject in our credit schedule. Occasionally, there are some departments of History where a few professors are devoted to the study of the Americas but links between History and English faculties are, unfortunately, not very common yet, even if some efforts are already being made to link us in some common research activities.

2 Furthermore, in Spain, English departments are often divided in two different sections; language and linguistics on the one hand, and literature and cultural studies on the other. Even when such division means an equalitarian correspondence in the number of credits, tradition usually prevails over the present socio-political situation and still the teaching of "English" (British and Irish) literature predominates over the teaching of North American matters. What it means, in practical terms, is that an average Spanish department of English may have in its syllabus for the undergraduate degree between 32 to 60 credits mostly dedicated to the teaching of American (United States) literature because, once again, there is a subsequent centralization of literature over other cultural matters. In sum, old academic privileges still reign in the Spanish University system while the more effective blurring of discipline boundaries existing in the US and in some European countries is only now starting to be felt here, academic research being probably the best indication that things are changing in our context.

The entrance of Spain, more than twenty years ago, in what is now the European Union meant, among many other things, a faster economic development of the country and the consolidation of academic links with many European and American universities. 
The Fulbright Commission, USIA, and the American Embassy in Madrid certainly provided Spanish scholars with favorable conditions to go to the US to further studies in an ample variety of fields. Such fields, of course, included literary and cultural studies, the result being that many of the faculty members teaching American literature and history in the Spanish University benefited from one international program or another.

4 From a purely administrative viewpoint, we can certainly conclude to the practical nonexistence of "American Studies" on an undergraduate level-but, perhaps, for a few credits in subjects usually named "Cultura e instituciones" or the like. Furthermore, there are not sufficient conditions yet to allow for a fruitful interchange between English and History departments. However, as happened in the USA some decades ago, the situation is gradually changing, mostly due to a fruitful research activity that is opening holes in the rigid administrative structures of the Spanish University.

5 If the postmodern condition brought about, among many other things, the questioning of the strict limits imposed by traditional thinking, and the subsequent recognition of the multifarious conditions of life, the Spanish Academe could not resist such ideological attacks for long. This meant, in practical terms, that in post-Franco Spain, by the beginning of the 1980s we had almost abandoned the exclusive close-reading or biographical approaches to the study of literary matters. Feminism, psychoanalysis, deconstruction, and cultural studies gradually took over, soon to be followed by the new perspectives on life provided by chaos theorists, the recognition of other minorities, and topics referred to the conditions of the self, hybridism, or the neverending critical dispute between nature and nurture. Amidst such cultural mixture, our critical methods, frequently eclectic, were also on the move and with it our very object of analysis: literature, as an aim in itself was gradually-and smoothly-displaced by the notion that literary matter is also a cultural symptom and therefore a means to investigate the conditions of society at any given time. In other words, we followed the critical path opened in the USA a few years earlier even if we did not have the administrative capacity to implement American Studies as a regular degree.

6 As an aftermath of the (failed?) « postmodern » revolution, scholars have provisionally concluded that humans are eminently discursive animals and values are never natural or universal; therefore, we should not try to impose our own values-or lack of themon other people by force. However, it is by now also a well-known and extended fact that most politicians-at least in the Western part of the planet-have not read Foucault, Derrida or Levinas, not to mention Lacan, Kristeva or Butler, and simply try to ignore the fact that other people may think different and be, at least in part, right in their perspective. Spanish politicians, unfortunately, are not exceptional in this sense and are now involved in the task of, once again, making university life a bit harder for students and faculty alike. For some years now, the Spanish Government seems to have declared war against University departments by insisting on their belief that the Spanish University should be much more competitive, by this meaning, of course, immediate economic profitability. This implies, on the one hand, that universities cannot raise matriculation fees to bear the real costs generated by students-all of them, rich or poor, intelligent or blockhead, have to be subsidized by university budgets-while the flow of public income is being systematically reduced so that universities need to raise money elsewhere. However, on the other hand, the 
Government does not apply any favorable fiscal policy that could lure private money into funding university programs.

7 Spanish politicians-historically well known for their smart understanding of the living conditions of the people-now try to complete their job by forcing the Spanish University system to reduce dramatically the number of degrees. Once again, demands are made especially to the Humanities, the intention being to replace old traditional degrees by new ones more responsive to the present socio-economic conditions of the country-that is to say, to the impulse of liberal anti-ecological globalization. The main excuse that the Government of Spain has given to force us into this dramatic reduction is an apparent necessity to unify the number and nature of our academic degrees with the rest of the European Union, an imperative necessity whose origin, though, cannot be traced anywhere in European legislation.

What all this political interference means in practical terms is that, at present, even the current BA degree in English provided by Spanish universities is at peril. If we cannot maintain the degree, the prospects for American Studies in Spain at the undergraduate level are not very optimistic; we will be lucky if we are allotted a few credits in a new general degree in Modern Languages, where perhaps the totality of English Studies will soon be allocated.

9 A certain hope remains, however, at the level of postgraduate studies. Some universities may eventually start new MA degrees or maintain doctoral programs where English and American Studies may coexist even with the added help of some specialized courses in linguistics, but the present situation is still rather obscure.

10 An exception to the existing panorama is the Research Institute for North American Studies, originally founded in 1986 within the University of Alcalá, in Madrid (http:// www.iuien-uah.net/). The Institute develops teaching and research programs in American Studies that try to match North American excellence but they also offer a degree in Spanish Studies aimed at North American students. Still a very young institution, the Institute is, at present, organizing a new MA degree in American Studies, the only one in the country, which benefits from the technical possibilities developed with Internet. This institution at the University of Alcalá is also in charge of a doctoral program in American Studies that has been running for two years now, being one among very few academic places where members of different English and History departments meet to carry out a unified curriculum. The Research Institute for North American Studies also sponsors Revista Española de Estudios Norteamericanos (REN), a biannual publication founded in 1989 (http://www2.uah.es/iuen/reden/contents.htm).

11 American Studies in Spain has traditionally benefited from a national forum in AEDEAN, the Spanish Association of Anglo-American Studies-also the Spanish associate member of EAAS. The institution was founded in Seville in the year 1976 by a small number of university professors who mostly belonged to the few English departments existing in Spain at the time. Now it has a membership of about 1,300 professors, lecturers, and graduate students from Spanish universities and abroad. AEDEAN has been holding an annual conference since 1977, always in the month of December, which, on average, brings together three to five hundred of its members. The Association also sponsors one of the oldest critical reviews of English Studies in Europe, Atlantis, now online at http://www.atlantisjournal.org/, which also features a number of articles on North American culture-mostly on its literature. Both the annual conference and the biannual review are dedicated to the study of the different 
branches of language, linguistics, and cultural studies in English. Within the latter field, literature studies still rule even if their research aims have become rather encompassing. One of the officers of AEDEAN's Executive Board has to be a specialist in American Studies and is in charge of all matters related to our field of study. The AEDEAN annual conference traditionally includes one panel dedicated to American Studies. The panel for our 2005 Conference is divided in five sessions where seven individual papers and three round tables are to be presented. Topics vary from the study of specific aspects in the writing of Flannery O'Connor, Ana Mendieta and Migdalia Cruz, Gordon Henry Jr., Elizabeth Bishop, or Chuck Palahniuk to extended discussions about masculinities and femininities, immigrant women writers, or hybrid literatures in North America. In general, we can affirm that literary studies still predominate over other matters, but the increasing hybrid nature of our studies and their diverse approaches are aspects quite noticeable in the program.

The fact that AEDEAN is dedicated to the study of all branches of English language and culture, together with the progressive specialization of faculty members, eventually brought ab out the birth of different smaller national forums dedicated to more specific fields of study. Among other academic groups, Spanish researchers in the culture of the United States decided to create their own specific association. As described in their web page (http://www.saasweb.org), the Spanish Association for American Studies (SAAS) was founded in Madrid in 1993, and was formally registered as 'Sociedad española para el estudio de los Estados Unidos de América.' Its aim is to promote and encourage the study of all areas of American Studies, assisting individuals and groups in developing their work and sharing their cultural and scientific interests." SAAS has a current membership of over one hundred and thirty professors and lecturers of American literature and History who mostly work in Spanish universities. This association collaborates in the publication of an annual critical review, Revista de Estudios Norteamericanos (REN), also sponsored by the University of Seville, a journal that, since its foundation in 1993, has published peer-reviewed papers strictly dedicated to the study of North American literature and culture.

The topics selected for the biennial conferences that SAAS has celebrated so far may give European readers a certain indication of the type of research that Spanish scholars have been developing in later years. The first conference was held in Madrid, its chosen topic being "History and Fiction: Fictions of History" (1994). Subsequent meetings, held in different Spanish cities, featured the following themes and topics: "Urban U.S.A.: Real and Imaginary Cities" (1995), "Century Ends, Crises and New Beginnings" (1997), "Travelling Across Cultures: The Twentieth-Century American Experience" (1999), "Power and Culture: Forms of Interaction and Renewal" (2001), "American Mirrors: Sef-Reflections and Self-Distortions" (2003), and "Masculinities, Femininities and Hybridities in U.S. Culture" (2005). These conferences have regularly attracted over one hundred participants from Spain and abroad. Their format includes plenary lectures (usually five), panel sessions (twelve to sixteen), dialogue sessions, roundtables, and workshops on specific issues or areas of study. In March 2007, the Universidad de Coruña will host the 8th SAAS Conference, its tentative title being, "Secrets: The Politics, Poetics and Ethics of Secrecy in U.S. culture."

Within this complex academic panorama, there is no clear unified view of method, corpus or research aims that may sufficiently encompass what scholars in American 
Studies are now doing in Spain. Certainly, the imprints of the different poststructuralisms and feminisms are still traceable in the research of many colleagues. But so are film studies, problems of identity, queer studies, the impact of scientific theories on literature, eco-criticism, and the demands for ethics in contemporary culture, as well as the increasing importance of Chicano literature and the presence of the other Americas in the culture of the United States. Different research teams and individual scholars, amidst the chaotic administrative situation of the Spanish University, keep on going in the hope that the future will soon bring us a little sunshine...

INDEX

Keywords: Literature, culture, hybridities, Psychoanalysis, Feminism, AEDEAN, SAAS, deconstruction, cultural studies, minorities 